\title{
Production Planning and Information Systems
}




\title{
Production Planning and Information Systems
}

\author{
J. J. Verzijl \\ N.V. Philips' Gloeilampenfabrieken, \\ Eindhoven, Holland
}

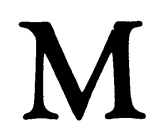


English edition @ J. J. Verzijl 1976

Softcover reprint of the hardcover 1st edition 1976 978-0-333-19210-8

All rights reserved. No part of this publication may be reproduced or transmitted in any form, or by any means, without permission

First published 1976 by

THE MACMILLAN PRESS LTD

London and Basingstoke

Associated companies in New York Melbourne

Dublin Johannesburg and Madras

ISBN 978-1-349-81522-7 ISBN 978-1-349-81520-3 (eBook)

DOI 10.1007/978-1-349-81520-3

This book is sold subject to the standard conditions of the

Net Book Agreement 


\section{Contents}

Preface vii

Introduction 1

1 Planning 3

2 Information $\quad 18$

3 'Available capacity equals capacity in demand' 27

4 Human performance $\quad 35$

$\begin{array}{lll}5 & \text { Heuristic scheduling } & 37\end{array}$

6 Frequent 'work' mixes 42

7 Six examples of planning in a factory 58

8 Worked example of a production department 67

9 Policy information $\quad 88$

$\begin{array}{ll}\text { Appendix: } & \text { Planning factors } \\ & 120\end{array}$

$\begin{array}{ll}\text { Index } & 123\end{array}$ 


\section{Preface}

The simultaneous production of several more or less complex commodities could not possibly be organised properly without using a great many systems competently and in proper balance, for instance systems of planning and information, estimating and post-calculation, rating, wage and salary information, work-structuring, training, career planning, co-ordination and costing. None of these is completely self-sufficient in the sense of being able to stand alone.

Planning systems can no more exist without information than fire without oxygen and are prone to fail whenever information is overdue or incomplete. Assuming that all the other systems involved are up to standard, the remedy lies in the efficient use of computers and business machines. However, since this study concerns only planning and information, the other systems will only be mentioned very briefly, as the occasion demands.

The principles and formulae on which to build systems of planning and information are shown to be no more complicated than the four 'simple' equations defining all the marvels of electricity and magnetism which are part of our daily lives and the source of all electrical equipment from electric lamps to space-craft, and from the hot-plate to the television receiver. Properly applied, these principles and formulae can go a long way towards ensuring a high standard of performance and good working conditions in any manufacturing department or factory.

Eindhoven, 1976

J. J. VERZIJL 